\title{
A szervesanyag lebontás lehetséges háttérmechanizmusai védett homokpusztagyepeken
}

\author{
Seres Anikó ${ }^{1}$, Szakálas Judit ${ }^{1}$, Nagy Péter ${ }^{1}$ Boros Gergely ${ }^{1,3}$, Kampfl

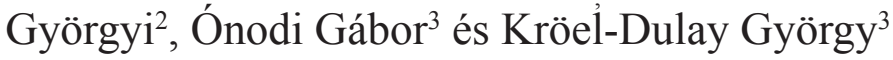 \\ ${ }^{1}$ Szent István Egyetem, Állattani és Állatökológiai Tanszék, \\ Páter K. u. 1, H-2100 Gödöllö \\ ${ }^{2}$ Szent István Egyetem, Környezettudományi Intézet, Kémia Tanszék, \\ Páter K. u. 1, H-2100 Gödöllö \\ ${ }^{3}$ Magyar Tudományos Akadémia, Ökológiai Kutatóközpont, Ökológiai és Botanikai \\ Intézet, 2163, Vácrátót, Alkotmány u. 2-4. \\ e-mail:seres.aniko@mkk.szie.hu
}

\begin{abstract}
Összefoglaló: A holt szervesanyag lebomlása a szénkörforgalom egyik fontos eleme. Kísérletünk az ExDrain (Extreme Drought and Chronic Rain Manipulation Experiment) projektben kapott lebontási mintázatok magyarázatához szolgáltat adatokat. Eddigi eredményeink alapján jelentős különbségeket találtunk a fülöpházi védett homokpusztagyepeken a két domináns füfaj (Festuca vaginata, Stipa borysthenica) hajtásainak és gyökereinek lebomlási sebességében. Azonban arról, hogy a mikrobiális bontáson túl a talajfauna mely tagjai és milyen mértékben vesznek részt a lebontásban, nincsen információnk. Ez egy szélsőségesen száraz terület, a makrofauna tagjai szinte teljesen hiányoznak. Ezért valószínüsíthető, hogy a mezofaunához tartozó ugróvillások nemcsak indirekt módon, a mikroba populációk szabályozásával, hanem direkt módon, a talajba került szervesanyagok elfogyasztásával is jelentős mértékben részt vesznek a lebontó folyamatokban. Laboratóriumi vizsgálatunk során a kérdéseink a következőek voltak: (i) kimutatható-e preferencia az ugróvillások táplálékválasztásában a két domináns füfaj gyökerei és hajtásai, illetve egyazon faj gyökere és hajtása között? (ii) Milyen háttérváltozókkal (a növények kémiai összetétele) magyarázható ez a preferencia? A táplálékválasztási tesztekben kapott eredmények jól magyarázzák az előzetes terepi vizsgálatainkban kapott adatokat, mivel a gyorsabban bomló füfajok illetve növényi részek iránti preferencia egyértelmúen kimutatható volt. A magas lignin- és alacsony $\mathrm{N}$ tartalmú táplálékot az állatok mind a laboratóriumban, mind a terepen elkerülték.
\end{abstract}

Kulcsszavak: ugróvillás, táplálékpreferencia, dekompozíció, ürülékszámolás, Folsomia candida

\section{Irodalmi áttekintés}

A talajokban a holt szervesanyag tartalom lebomlás sebessége és módja kulcskérdés a gyepek tápanyag-gazdálkodásában. A talajok szervesanyag-tartalmának vál- 
tozása a globális klímaváltozás függvényében egy kiemelt kutatási terület, mert a lebomlás sebességének egyik legfontosabb szabályozója a klíma, elsősorban a talaj hőmérséklete és páratartalma (Kirschbaum 1995, van Meeteren et al. 2008, Smith 2012). A klímán kívül fontos paraméter a talajba bekerülő szervesanyag minősége, annak kémiai összetétele (Swift et al. 1979, Aerts 1997, Almagro \& Martinez-Mena 2012). A harmadik meghatározó tényezője a dekompozíciónak a folyamatban résztvevő szervezetek (talajállatok, mikrobák) minőségi összetétele és mennyisége. A talajfaunának elvitathatatlan szerepe van a növényi részek feldarabolásában, amely folyamat során a kémiai bontást végző mikrobák hozzáférhetnek a bontandó szerves anyagokhoz. Ebben a folyamatban, a legtöbb talajtípusban a makrofauna tagjai (gyürüsférgek, ászkák és ikerszelvényesek) játsszák a legnagyobb szerepet (Slade \& Riutta 2012). A mezofauna tagjai (atkák, ugróvillások) is fogyasztanak elhalt szerves anyagokat, de ennek a mennyisége a makrofauna által feltárt növényi részekhez képest elhanyagolható, őket inkább a baktériumok és gombák szelektív fogyasztása révén a lebontó folyamatok szabályozóiként tartjuk számon (Bakonyi 1989). Azonban az olyan szélsőségesen száraz élőhelyeken, mint egy nyílt homokpusztagyep, a makrofauna legtöbb képviselője hiányzik. Irodalmi adatok (Pant et al. 2017) és terepi tapasztalataink (Seres et al. 2015, Szakálas et al. 2015) alapján feltételezzük, hogy ezen az élőhelyen az ugróvillások nem csak indirekt módon, a lebontó mikroorganizmusok (baktériumok, gombák) populációinak szabályozásával, hanem direkt módon, a növényi részek elfogyasztásával is jelentős mértékben részt vesznek a lebontó folyamatokban.

A kísérleti területen eddig végzett ugróvillásközösség-szerkezeti vizsgálatok során egy olyan fajt találtak, az Entomobrya nigriventris-t, ami dominánsnak bizonyult az ottani közösségben (Flórián et al. 2016). A vizsgált mintákban mintegy 90 százalékos volt az előfordulási aránya. Kísérleteinkbe ezt a fajt nem tudtuk bevonni, mert nem sikerült laboratóriumi körülmények között hosszabb ideig életben tartani. Azonban a laboratóriumban könnyen tartható fajok közül is sikerült a területen kimutatni a Folsomia candida faj előfordulását ugyanebben a tanulmányban. A legtöbb ugróvillás faj táplálkozási spektruma tág határok között mozog. Fogyaszthatnak többek között különböző mohákat, növényi maradványokat, elhalt szerves anyagokat, gombafajok spóráit, hifáit, baktériumokat, fonálférgeket, algasejteket és zuzmókat (Anderson \& Healey 1972; Bakonyi et al. 1994; Bakonyi 1998; Gilmore \& Potter 1993). Ezen kívül fontos szerepük lehet a talajban élő szaprofita és mikorrhiza gombák terjesztésében is (Seres és Bakonyi 2002, Seres et al. 2003). Több vizsgálatban is kimutatták, hogy ezek az állatok finom skálán (akár gomba törzsek között is különbséget téve) képesek válogatni a felkínált táplálékok között és szükségleteiknek megfelelően állítják össze az 
étrendjüket, a számukra nem elég jó minőségü táplálékot elkerülik (Bakonyi et al. 2006).

Egy korábbi kísérletünkben (Seres et al. 2015) a szervesanyag lebomlását vizsgáltuk különböző módszerekkel egy homokpusztagyepen, szintén az ExDRain projekt keretében. A „minikonténer” technikával a két domináns füfaj lebomlását követtük figyelemmel. Vizsgáltuk, hogy van-e az egyszeri aszálykezelésnek kimutatható hatása a dekompozícióra, illetve, hogy van-e a növényfajoknak (Festuca vaginata, Stipa borysthenica) és növényi részeknek (gyökér és hajtás), illetve a talajmélységnek hatása a lebomlás sebességére? Jelen vizsgálatunk szempontjából fontos, hogy mind a növényfajnak, mind a növényi résznek erős szignifikáns hatása volt a lebomlás intenzitására. A tömegveszteség nagyobb volt a Festuca vaginata fajnál és a növények hajtása esetében. Azaz a növényi részek között jelentős különbségeket találtunk a lebomlás sebességében, ami feltételezhetően a növényfajok és részek közötti kémiai különbségekkel magyarázható. Ezen eredmények tükrében terveztük meg a jelen vizsgálatot. Kérdéseink a következőek voltak: (i) kimutatható-e preferencia az ugróvillások táplálékválasztásában a két domináns fúfaj gyökerei és hajtásai, illetve egyazon faj gyökere és hajtása között? (ii) Milyen háttérváltozókkal magyarázható ez a preferencia a növények kémiai összetétele alapján?

\section{Módszerek}

A Folsomia fimetaria (Linnaeus, 1758), a Folsomia candida Willem 1902 és a Sinella magyari Chen, Wang, F \& Christiansen, 2002 (Chen et al. 2002) ugróvillás fajokhoz tartozó állatok a Szent István Egyetem (SZIE) Állattani és Állatökológiai Tanszékének tenyészetéből származtak. Az állatokat klímakamrában sötétben tartjuk, $20 \pm 1{ }^{\circ} \mathrm{C}$-on, szénnel kevert gipsz felületén és szárított élesztőt kapnak táplálékként. Az állatokat egyedileg teszteltük 3 centiméter átmérőjü Petri-csészékben. A Petri-csészékbe szürőpapírt helyeztünk, amit nedvesítettünk. A szürőpapír tetejére került egy kinyomtatott ábra (1. ábra), ahol a körök közepébe helyeztük el a kétféle táplálékot. Mindegyik ugróvillás faj esetében 20-30 közötti ismétléssel hajtottuk végre a kísérleteket a négy kombinációval. A laboratóriumi termosztátban $20 \pm 1{ }^{\circ} \mathrm{C}$-os állandó hömérsékleten tartottuk az állatokat, majd 10 nap elteltével bontottuk a kísérletet. A vizsgálatot az alábbi párosítások alapján végeztük: Stipa borysthenica hajtás - Stipa borythenica gyökér, Festuca vaginata hajtás - Festuca vaginata gyökér, Stipa borysthenica hajtás - Festuca vaginata hajtás, Stipa borysthenica gyökér - Festuca vaginata gyökér. A 10 napos inkubációs idő után a táplálékfoltokon, illetve a táplálékfoltok közvetlen közelében 


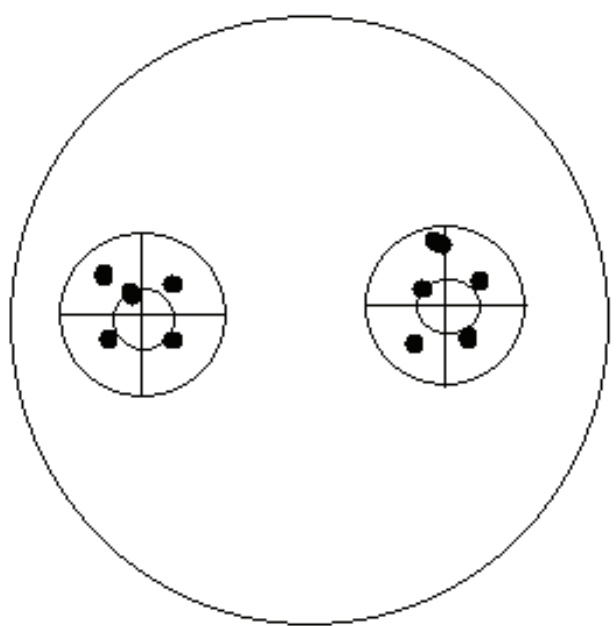

1. ábra: A kísérleti elrendezés. A kisebb körök közepére kerültek a táplálékszemcsék, a nagyobb körökön belül számoltuk az ürüléket.

található ürülékszemcséket számoltuk. Az ugróvillások a gyors anyagcseréjük miatt ott ürítenek, ahol táplálkoznak, ezért az egyes táplálékforrások közvetlen környezetében elhelyezkedö ürülékszemcsék számából következtetni lehet a táplálékpreferenciára (Bakonyi et al. 2006). A kísérletet megelőző időszakban meghatároztuk a Stipa borysthenica és a Festuca vaginata hajtásainak és gyökereinek beltartalmi értékeit. A C/N analízist a SZIE Kémia Tanszékén egy Carlo-Erba NA 1500 típusú elemanalizátorral, a cellulóz, hemicellulóz és lignin beltartalmi értékeinek kielemzését pedig van Soest 1963-ban kidolgozott módszere alapján a SZIE Takarmányozástani Tanszékén készítették el (van Soest 1963). A statisztikai értékelést $\mathrm{R}$ környezetben végeztük, a növények beltartalmi értékeinél az alkalmazhatósági feltételek ellenőrzése után egyutas ANOVA-t, majd Tukey post hoc tesztet végeztünk. Az ürülékszemcsék számát a két felkínált táplálékon páros t-teszttel hasonlítottuk össze.

\section{Eredmények}

Az 1. táblázatban mutatjuk be a növények beltartalmi elemzésének eredményeit. A táblázatból látható, hogy a statisztikai értékelés jelentős különbségeket mutatott az egyes növényi részek között. A táplálékválasztás szempontjából két legfontosabb paraméter a $\mathrm{N}$ - és a lignintartalom illetve a $\mathrm{C} / \mathrm{N}$ arány a következő módon alakult. A növényi részek $\mathrm{N}$ tartalma az alábbi sorrendben csökkent: Festuca hajtás, Stipa hajtás, Festuca gyökér, Stipa gyökér. Az első három növényi rész esetében a különbségek statisztikailag igazolhatóak, de jóval kisebbek, mint a Stipa 
1. táblázat: A preferenciavizsgálatok során felkínált növényi részek kémiai összetétele (10 ismétlés átlaga \pm szórás). A különböző betük statisztikailag igazolható különbséget jelentenek (Tukeyteszt, $\mathrm{p}<0,05)$.

\begin{tabular}{lccccc}
\hline & Festuca hajtás & $\begin{array}{c}\text { Festuca } \\
\text { gyökér }\end{array}$ & Stipa hajtás & Stipa gyökér & F-érték \\
\hline C (\%) & $45,19 \pm 0,71 \mathrm{bc}$ & $44,06 \pm 0,34 \mathrm{~b}$ & $46,71 \pm 0,11 \mathrm{c}$ & $40,51 \pm 1,71 \mathrm{a}$ & $39 * * *$ \\
$\mathrm{~N}(\%)$ & $1,20 \pm 0,03 \mathrm{c}$ & $1,04 \pm 0,04 \mathrm{~b}$ & $1,13 \pm 0,04 \mathrm{c}$ & $0,57 \pm 0,02 \mathrm{a}$ & $328^{* * *}$ \\
$\mathrm{C} / \mathrm{N}$ & $37,70 \pm 1,44 \mathrm{a}$ & $42,52 \pm 2,02 \mathrm{~b}$ & $41,08 \pm 1,44 \mathrm{ab}$ & $70,51 \pm 2,83 \mathrm{c}$ & $282^{* * *}$ \\
Lignin (\%) & $5,29 \pm 0,13 \mathrm{a}$ & $14,43 \pm 0,23 \mathrm{c}$ & $9,43 \pm 0,19 \mathrm{~b}$ & $18,47 \pm 0,33 \mathrm{~d}$ & $6153^{* * *}$ \\
Cellulóz (\%) & $32,93 \pm 0,51 \mathrm{~b}$ & $35,94 \pm 0,38 \mathrm{c}$ & $29,59 \pm 0,60 \mathrm{a}$ & $39,63 \pm 0,55 \mathrm{~d}$ & $687^{* * *}$ \\
Hemicellulóz(\%) & $27,19 \pm 0,94 \mathrm{c}$ & $25,54 \pm 0,60 \mathrm{~b}$ & $29,46 \pm 1,65 \mathrm{~d}$ & $17,79 \pm 0,79 \mathrm{a}$ & $225^{* * *}$ \\
\hline
\end{tabular}

gyökér esetében, ahol az érték majdnem a fele a többi értéknek. A C/N értékek alakulása is hasonló, a legkedvezőbb C/N értéket a Festuca hajtás, míg messze a legrosszabb C/N értéket a Stipa gyökér esetében kaptuk. A Stipa hajtás és a Festuca gyökér valamint a Festuca hajtás és a Stipa hajtás C/N tartalma nem különbözik szignifikánsan. A Festuca hajtás és a Festuca gyökér között viszont ez a különbség statisztikailag is igazolható. A Stipa gyökér $\mathrm{C} / \mathrm{N}$ aránya minden más növényi részétől magasabb, azaz egy egység C-re itt esik a legkisebb mennyiségü $\mathrm{N}$. A nehezen emészthetö lignin tartalom a $\mathrm{N}$ tartalom csökkenésnek megfelelö sorrendben növekedett a növényi részekben (Festuca hajtás, Stipa hajtás, Festuca gyökér, Stipa gyökér). Itt a különbségek azonban jóval nagyobbak voltak, mint a $\mathrm{N}$ esetében és mindenhol statisztikailag igazolhatóak. A cellulóz tartalom a Stipa gyökérben volt a legmagasabb és a Stipa hajtásban a legalacsonyabb, míg a hemicellulóz mennyisége éppen fordítva a Stipa hajtásban bizonyult a legmagasabbnak és a Stipa gyökérben a legalacsonyabbnak. A táplálékválasztási tesztek eredményeit a 2. táblázatban mutatjuk be. Az eredményekböl jól látható, hogy a Folsomia

2. táblázat: Az egyes ugróvillás fajok ürülékszemcséinek a száma (minimum 20 ismétlés átlaga, $\mathrm{db} \pm$ szórás) és a páros t-teszt eredményei láthatóak ( $\mathrm{p}<0,05:^{*}, \mathrm{p}<0,01:^{* *}, \mathrm{p}<0,001:^{* * *}, \mathrm{n} . \mathrm{sz} .:$ nem szignifikáns).

\begin{tabular}{lccc}
\hline & Folsomia candida & Sinella magyari & Folsomia fimetaria \\
\hline Festuca hajtás & $112 \pm 36^{* * *}$ & $50 \pm 21^{* * *}$ & $64 \pm 26^{* * *}$ \\
Festuca gyökér & $50 \pm 25$ & $14 \pm 11$ & $30 \pm 22$ \\
Stipa hajtás & $104 \pm 48^{* * *}$ & $49 \pm 29^{* * *}$ & $54 \pm 31^{* *}$ \\
Stipa gyökér & $42 \pm 25$ & $19 \pm 14$ & $33 \pm 16$ \\
Festuca hajtás & $114 \pm 50 \mathrm{n} . \mathrm{sz}$. & $37 \pm 24^{* *}$ & $51 \pm 25^{*}$ \\
Stipa hajtás & $114 \pm 55$ & $21 \pm 16$ & $36 \pm 24$ \\
Festuca gyökér & $42 \pm 35 \mathrm{n} . \mathrm{sz}$. & $21 \pm 15 \mathrm{n} . \mathrm{sz}$. & $30 \pm 13^{*}$ \\
Stipa gyökér & $35 \pm 35$ & $20 \pm 17$ & $20 \pm 13$ \\
\hline
\end{tabular}


fimetaria esetében minden párosításnál volt egy preferált táplálék, a $F$. candida ugróvillás fajnál a négyből kettő, míg a $S$. magyari fajnál három esetben találtunk preferenciát. A $F$. fimetaria ugróvillás mindkét fúfaj esetében a hajtásokat preferálta. A fajok közül mind a hajtások, mind a gyökerek összehasonlításánál a Festuca vaginata fajt fogyasztotta nagyobb mennyiségben. A F. candida ugróvillás a növényfajok között nem válogatott, azonban a hajtások gyökerekkel szembeni preferenciája mindkét fúfaj esetében megfigyelhető volt. Ez utóbbi jelenség a Sinella magyari ugróvillás fajnál is jól kimutatható volt, a hajtások esetében pedig ez a faj is a Festuca vaginata füfajt részesítette elönyben. A két füfaj gyökerei között viszont nem találtunk ennél az ugróvillásnál sem preferenciát. Összességében a növények hajtásai és a Festuca vaginata növényfaj volt a kedveltebb tápláléka az ugróvillásoknak, ezzel ellentétes preferenciát sehol sem találtunk.

\section{Értékelés}

Az ugróvillásokat az irodalomban sokáig fungivoroknak tekintették, bár az már régóta ismert tény, hogy rendkívül változatos lehet az elfogyasztott táplálékuk összetétele. Az utóbbi években egyre több vizsgálat támasztja alá, hogy ezek az állatok elhalt és élő növényi táplálékot is fogyasztanak (Malcika et al. 2017), akár nagy mennyiségben is. Jelen vizsgálat is igazolja ezt, bár ebben a kísérleti beállításban nem állt rendelkezésre az állatok számára alternatív táplálék. Chahartaghi és munkatársai (2015) N izotópos vizsgálatai szerint ezek az állatok nem sorolhatóak egyértelmủ táplálkozási guildekbe, mert képesek másfajta táplálékra áttérni, ha annak a rendelkezésre állása megváltozik.

A táplálékválasztási tesztekben kapott eredmények jól magyarázzák az előzetes terepi vizsgálatainkban kapott adatokat (Seres et al. 2015), amennyiben a gyorsabban bomló füfajok, illetve növényi részek iránti preferencia egyértelmüen kimutatható volt. Az ugróvillások táplálékpreferenciájának két fontos mozgatórugója van, az egyik a táplálék $\mathrm{N}$ tartalma, illetve $\mathrm{C} / \mathrm{N}$ aránya. Az állatok általában a magasabb $\mathrm{N}$ tartalmú és alacsonyabb $\mathrm{C} / \mathrm{N}$ arányú táplálékot választják az irodalmi adatok szerint (Larsen et al. 2008). Esetünkben ez a mintázat jól megfigyelhető volt: a legalacsonyabb $\mathrm{N}$ tartalmú táplálékot (Stipa gyökér) egyetlen esetben sem választották az állatok, míg a legmagasabb $\mathrm{N}$ tartalmú táplálékot (Festuca hajtás) szinte minden esetben jobban kedvelték a többinél. A táplálékválasztás másik fontos meghatározója a nehezen emészthető anyagok minél kisebb mennyisége. Mivel a nehezen bomló lignin tartalom ugyanabban a sorrendben növekedett a növényi anyagokban, ahogy a $\mathrm{N}$ tartalom csökkent így az előzőekben leírt jelenség itt is igaz. A magas lignin (és egyben alacsony N) tartalmú táplálékot az állatok a 
laboratóriumban elkerülték, amely a terepen tapasztalt eredményeket megerősíti. Arányaiban azonban a lignin tartalomban voltak a legnagyobb különbségek a növényi részek között (Stipa gyökér: 18\%, Festuca hajtás: 5\%), így ezen vizsgálat alapján a lignin tartalom fontosságát hangsúlyoznánk az állatok táplálékválasztásban.

Mindezek alapján feltételezzük, hogy a laboratóriumban és a terepen (Seres et al. 2015) kapott hasonló mintázatot az okozza, hogy az ugróvillások valóban közvetlenül is résztvesznek a szervesanyagok lebontásában ezen a szélsőségesen száraz élőhelyen. Így az ugróvillások populációváltozásainak nyomon követése különösen fontos védett homokpusztagyepeink tápanyag-gazdálkodása szempontjából.

Köszönetnyilvánítás - A vizsgálat az Emberi Erőforrások Minisztériuma ÚNKP-174 kódszámú Új Nemzeti Kiválóság Programjának és az Országos Tudományos Kutatási Alapprogram (K112576) támogatásával készült.

\section{Irodalomjegyzék}

Aerts, R. (1997): Climate, leaf litter chemistry and leaf litter decomposition in terrestrial ecosystems: a triangular relationship. - Oikos 79: 439-449. doi: https://doi.org/10.2307/3546886

Almagro, M. \& Martinez-Mena, M. (2012): Exploring short-term leaf-litter decomposition dynamics in a Mediterranean ecosystem: dependence on litter type and site conditions. - Plant Soil 358: 323-335. doi: https://doi.org/10.1007/s11104-012-1187-6

Anderson, J., M. \& Healey, I. N. (1972): Seasonal and Inter-Specific Variation in Major Components of the Gut Contents of Some Woodland Collembola. - J. Anim. Ecol. 41: 359-368. doi: https:// doi.org/10.2307/3473

Bakonyi, G. (1989): Effects of Folsomia candida (Collembola) on the microbial biomass in a grassland soil. - Biol. Fert. Soils 7: 138 -141. doi: https://doi.org/10.1007/BF00292572

Bakonyi, G. (1998): Nitrogen turnover of Sinella coeca (Collembola: Entomobryidae). - Eur. J. Entomol. 95: 321-326.

Bakonyi, G., Dobolyi, C. \& Le, B. T. (1994): $15 \mathrm{~N}$ uptake by collembolans from bacterial and fungal food source. - Acta Zool. Fenn. 194: 136-138.

Bakonyi, G. Szira, F. Kiss, I., Villányi, I., Seres, A. \& Székács, A. (2006): Preference tests with collembolas on isogenic and Bt-maize. - Eur. J. Soil Biol. 42: 132-135. doi: https://doi.org/10.1016/j. ejsobi.2006.06.005

Chahartaghi, M, Langel, R., Scheu, S. \& Ruess, L. (2005): Feeding guilds in Collembola based on nitrogen stable isotope ratios. - Soil Biol. Biochem. 37: 1718 -1725. doi: https://doi.org/10.1016/j. soilbio.2005.02.006

Chen, J., Wang, F. \& Christiansen, K. (2002): A New Species of the Subgenus Coecobrya from Hungary (Collembola: Entomobryidae). - J. Kansas Entomol. Soc. 75: 43-47.

Flórián, N., Dányi, L., Kröel-Dulay, Gy., Ónodi, G. \& Dombos, M. (2016): Repeated drought effects on the soil microarthropod communities of a sand steppe. - Abstract book of XVII International Colloquium on Soil Zoology, pp. 59. 
Gilmore, S. K. \& Potter, D. A. (1993): Potential role of Collembola as biotic mortality agents for entomopathogenic nematodes. - Pedobiologia 37: 30-38.

Kirschbaum, M. U. F. (1995): The temperature dependence of soil organic matter decomposition, and the effect of global warming on soil organic C storage. - Soil. Biol. Biochem. 27: 753-760. doi: https://doi.org/10.1016/0038-0717(94)00242-S

Larsen, J., Johansen, A., Larsen, S. E., Heckmann, L. H., Jakobsen, I. \& Krogh, P. H. (2008): Population performance of collembolans feeding on soil fungi from different ecological niches. - Soil Biol. Biochem. 40: 360-369. doi: https://doi.org/10.1016/j.soilbio.2007.08.016

Malcika, M., Berg, M.P. \& Ellers, J. (2017): Ecomorphological adaptations in Collembola in relation to feeding strategies and microhabitat. - Eur. J. Soil Biol. 78: 82-91. doi: https://doi. org/10.1016/j.ejsobi.2016.12.004

Pant, M., Negi, G.C.S. \& Kumar, P. (2017): Macrofauna contributes to organic matter decomposition and soil quality in Himalayan agroecosystems, India. - Appl. Soil Ecol. 120: 20-29. doi: https://doi.org/10.1016/j.apsoil.2017.07.019

Seres, A. \& Bakonyi, G. (2002): A talajlakó állatok és az endomikorrhiza-gombák közötti kapcsolatok szerepe a növények tápanyagellátásában. - Agrokémia és Talajtan. 51: 535-546. doi: https:// doi.org/10.1556/Agrokem.51.2002.3-4.17

Seres, A., Bakonyi, G. \& Posta, K. (2003): Ugróvillások (Collembola) szerepe a Glomus mosseae (Zygomycetes) arbuszkuláris mikorrhiza gomba terjesztésében. - Állattani Közl. 88: 61-71.

Seres, A, Tóth, Zs., Hornung, E., Pörneki, A., Szakálas, J., Nagy, P. I., Boros, G., Ónodi, G. \& Kröel-Dulay, Gy. (2015): Szerves anyag lebomlás vizsgálatok módszertani kérdései egy védett homokpusztagyep talajában. - Termvéd. Közlem. 21: 262-270.

Slade, E. M. \& Riutta, T. (2012): Interacting effects of leaf litter species and macrofauna on decomposition in different litter environments. - Basic Appl. Ecol. 13: 423 -431. doi: https://doi. org/10.1016/j.baae.2012.06.008

Smith, P. (2012): Soils and climate change. - Curr. Opin. Environ. Sustainability 4: 539-544. doi: https://doi.org/10.1016/j.cosust.2012.06.005

Swift, M. J., Heal, W. O. \& Anderson, J. M. (1979): Decomposition in Terrestrial Ecosystems. Studies in Ecology 5. Blackwell Scientific, Oxford, UK

Szakálas, J., Kröel-Dulay, Gy., Kerekes, I., Seres, A., Ónodi, G. \& Nagy, P. (2015): Extrém szárazság és növényzeti borítottság hatása szabadon élő fonálféreg együttesek denzitására. - Termvéd. Közlem. 21: 293-300.

van Meeteren, M. J. M., Tietema, A., van Loon, E. E. \& Verstraten, J. M. (2008): Microbial dynamics and litter decomposition under a changed climate in a Dutch heathland. - Appl. Soil Ecol. 38: 119-127. doi: https://doi.org/10.1016/j.apsoil.2007.09.006

van Soest, P. J. (1963): Use of detergents in the analysis of fibrous feeds. II. A rapid method for the determination of fiber and lignin. -J. Assoc. Off. Anal. Chem. 46: 829-835. 


\title{
Laboratory food preference experiments with Collembola on the leaves and roots of two dominant grass species from a Hungarian grassland
}

\author{
Anikó Seres ${ }^{1}$, Judit Szakálas ${ }^{1}$, Péter István Nagy ${ }^{1}$ Gergely Boros ${ }^{1,3}$, \\ Györgyi Kampfl' ${ }^{2}$, Gábor Ónodi ${ }^{3}$ and György Kröel-Dulay ${ }^{3}$ \\ ${ }^{1}$ Szent István University, Department of Zoology and Animal Ecology, \\ H-2100 Gödöllö, Páter K. u. 1, Hungary \\ ${ }^{2}$ Szent István University, Department of Chemistry, \\ H-2100 Gödöllö, Páter K. u. 1, Hungary \\ ${ }^{3}$ Institute of Ecology and Botany, Centre for Ecological Research, Hungarian Acadamy \\ of Sciences, H-2163, Vácrátót, Alkotmány u. 2-4, Hungary \\ e-mail:seres.aniko@mkk.szie.hu
}

The Extreme Drought and Chronic Rain Manipulation Experiment (ExDRain) is conducted in a natural grassland ecosystem in central Hungary near Fülöpháza. Previously, we found a higher decomposition rate for grass leaves compared to grass roots, and higher decomposition of one dominant grass species (Festuca vaginata) over the other (Stipa borysthenica) in this experimental system. In the present study, we investigated if higher decomposition rate may be related to food preference of a potential decomposer in the system in a laboratory experiment, and posed the following questions: do Collembola (Folsomia candida, Folsomia fimetaria and Sinella magyari) select (1) between the two grass species (Festuca vaginata vs. Stipa borysthenica) and (2) between the two plant parts (leaves vs. roots) within the plant species? Paired choice assays were conducted in Petri-dishes. Significant differences were found in the food preference of Collembola species between the two parts of the plants and between the two plant species. The leaves and Festuca vaginata were more preferred food type as compared to roots and Stipa borysthenica. The chemical composition of the plant parts could explain the found patterns, especially the $\mathrm{N}$ and lignin content of the leaves and roots.

Keywords: springtails, food preference, decomposition, fecal pellet count, Folsomia candida 